Volume-V, Issue-02, July-December, 2010

\title{
Developing English Reading Skills of the Students of Business Administration at Private Universities in Bangladesh: Prospects and Problems
}

\author{
MD. GOLAM HOSHAIN MIRZA ${ }^{1}$
}

\begin{abstract}
This paper examines the efforts of the English language teachers who are working to develop English reading skills among the students studying in the Business Administration departments at ten of the English-medium private universities in Bangladesh. Adopting both the quantitative and the qualitative approaches, it analyses the data collected through student interview-schedule. The study identifies that, in spite of having good classroom facilities and necessary supplementary materials, the reading classes are not as effective as they could be. It is mainly because unsuitable materials are inappropriately used in a class of students with significantly different levels of proficiency. The paper finally suggests some measures that can be taken to make the reading class more effective. Among others, it recommends that the English teacher should involve first the university administration in forming the language class with students of similar proficiency level and then the BBA teachers in developing appropriate materials for it.
\end{abstract}

\section{INTRODUCTION}

Most of the BBA students at the private universities are from Bengali-medium schools and colleges. As expected, they are not very good at reading their study materials in English. So the immersion which they go through at the beginning of their university education is a difficult experience for many of them. They cannot keep pace with the academic activities. One of the reasons why they do not do well in the exams is that they cannot read and comprehend their books and other materials. Many of the students who drop out do so because they are unable to read in English. On the other hand, to make the immersion a success, the universities offer foundation courses. But every teacher who deals with the senior BBA students

\footnotetext{
${ }^{1}$ Assistant Professor, Department of English, Northern University Bangladesh, Dhaka
} 
knows that, after doing the courses, many of them remain too weak to read their things in English. Therefore, it is important to find out why teaching and learning of the reading skills for the BBA students is, to a great extent, ineffective. If the weaknesses are found, necessary steps can be taken to remove them.

\section{Literature Review}

Developing reading skills in the second language $\left(\mathrm{L}_{2}\right)$ has long been one of the main targets of the language teachers across the world. Researchers have found a lot about the nature of reading activity and how learners can be helped to develop their $\mathrm{L}_{2}$ reading skills in classroom environment. Nunan (1991) has discussed the major theories in this respect. At first we have the two classic approaches to reading, namely the bottom-up and top-down. According to the former, the readers decode the written symbols into their aural equivalents while the latter gives more importance to the reconstruction of meaning. The readers interact with the text and always try to form a meaning by using their knowledge of the subject and their knowledge about the language. And according to schema theory, a reader's interpretation of a text is determined to a great extent by his/her interests, motivations and background knowledge. Thus, readers are expected to read better if they know about the language, have the necessary schematic knowledge, and feel interested as well as motivated.

With regard to interests, Bhatia (2004) has stated that they are subject to factors like importance of the lesson, variety, and the teacher's enthusiasm and involvement. On the other hand, distraction may be caused by noise, abnormal temperature, uncomfortable seats, fear and anger. As for motivation, Brown (1994) and Deci (1975) have talked a lot about its nature and types. In the end, it has been concluded that no matter what type of motivation the learners have, they will learn if they are motivated to. And Elis (1999) has observed that the interests and motivations of the learners are determined and controlled by, among others, their attitude. Learners feel better and consequently learn better if their attitude towards their teachers and course materials is positive. In other words, reading is facilitated by comfortable classroom environment, the readers' motivations and their positive attitude.

As for the objective of the reading class, Ur (2003) states that it is mainly to expose the readers to authentic materials. According to Tomlinson (2003), a text written to exemplify linguistic aspects of the target language is not an authentic text. Therefore, course-book based materials might not be suitable for a particular learner or class. Ur (2003) has found five problems with them. Four of them are:

a) They might not meet the learning needs of the readers. 
b) The topics of the materials may not be relevant or interesting.

c) They might not suit different levels of ability and knowledge of the readers or their learning styles and strategies.

d) They might seem boring and monotonous.

Besides, successful reading of an authentic text requires actions like deduction, induction, inference, generalization, interpretation, recognition of the author's motives, etc. To involve the readers in these activities, many different steps can be taken. Widdowson (1978) talks of using language across the curriculum. Nunan (1991) suggests referential questions and competition among the students. Ur (2003) says that the content of the text should be interesting and the tasks challenging as well as of different types. About the level of the input, Krashen and Terrell (1983) talk of the Input Hypothesis: the language should be neither too easy nor too hard for the learners. And Finocchiaro and Brumfit (1983) recommends the 'judicious' use of $\mathrm{L}_{1}$. Therefore, materials for a particular class and the activities based on them are to be prepared with much care, and their effective use is to be ensured by experienced teachers.

\section{METHODOLOGY}

The study has been conducted on 50 subjects. During the period of data collection (Fall Semester - 2009), the subjects were studying in Department of Business Administration at different private universities in Bangladesh. All the subjects were from Bengali medium schools and colleges. The researcher selected the subjects from the students who had done the foundation courses, of which developing English reading skills was one of the main aims. The subjects were chosen from ten universities -5 subjects from one university. As the present study did not have the scope of including all the private universities, the researcher decided to deal with ten of them purposively. The researcher believes that ten private universities make up about $20 \%$ of the sector and, therefore, the finding(s) of the study will be as representative as possible of the whole scenario. Besides, the study should have considered the teachers' opinions about the situation and examined if the size of the class, the course duration, and the testing system have any role to play. But, due to the limited resources of the study, the researcher decided to leave them for further researches.

To collect data, the researcher prepared and used an interview-schedule. Before the subjects answered the questions, the researcher explained them to the subjects individually so as to avoid confusion. It was to ensure that the information given by the subjects was well thought out. The researcher adopted both the quantitative and the qualitative approaches for the study because some information was quantitative 
in nature and required quantitative interpretation while some questions were open ended and the information elicited by them needed qualitative treatment.

\section{DATA ANALYSIS}

The questions were used to collect data about the environment and facilities available in the classroom, the materials used in the classes, the teachers' role and their way of handling the classroom activities, and finally the learners' motivations for as well as opinions about the course.

\section{Classroom Environment}

The respondents have reported and the researcher has seen that the rooms where the classes were held were well furnished and well equipped. They were well-lit, spacious and tastefully curtained. They were air-conditioned too, with comfortable chairs for the students. Among the modern equipment, the classrooms had white boards and access to other supplementary materials like computers, multimedia, over head projectors, sound systems, printers and photocopiers.

\section{Pre-Reading Activities}

In the interview-schedule, 16 questions were used to find out about the three sections of the reading class, namely pre-reading, reading, and post-reading. The first 3 questions were intended to find out information about the activities done in the beginning of the class.

TABLE 1

PRE-READING ACTIVITIES IN THE READING CLASS

\begin{tabular}{l|c|c|c|c|c}
\hline \multicolumn{1}{c|}{ Questions } & Always \% & $\begin{array}{c}\text { Often } \\
\%\end{array}$ & $\begin{array}{c}\text { Sometimes } \\
\%\end{array}$ & $\begin{array}{c}\text { Rarely } \\
\%\end{array}$ & $\begin{array}{c}\text { Never } \\
\%\end{array}$ \\
\hline $\begin{array}{l}\text { 1. Did your teacher show any } \\
\text { pictures / maps / diagrams before } \\
\text { the class started reading? }\end{array}$ & 6 & 8 & 22 & 10 & 54 \\
2. Did your teacher ask you to \\
guess from the titles or other \\
clues?
\end{tabular}

Source: Field work, November, 2009 
As Table 1 shows, the schema building activities are not given their due importance. While $54 \%$ of the subjects have said that thought-provoking materials like pictures, maps and diagrams were 'never' used in their class, $48 \%$ of them have reported that their teachers 'never' asked them to anticipate or guess depending on any given clues. As for introductory discussion about the topics, $28 \%$ of the subjects have said that it was 'never' held.

\section{During Reading}

While doing the actual reading in the class, three parties interact with each other - the materials, the teacher and the learners. The researcher used 8 questions to collect data about all of them.

\section{Materials}

At first, there were 4 questions to find out about the sources, the genres and the levels of the materials as well as how they were used.

TABLE 2

SOURCES OF THE MATERIALS

\begin{tabular}{c|l|c}
\hline \multicolumn{1}{c|}{ Question } & Types of materials used in the class & Percent (\%) \\
\hline 4. What types of materials & Commercial & 62 \\
were used in the class? & Personally Developed & 0 \\
& Adapted & 0 \\
& Commercial and Personally Developed & 4 \\
& Commercial and Adapted & 24 \\
& Personally Developed and Adapted & 2 \\
& All these types & 8 \\
\hline
\end{tabular}

Source: Field work, November, 2009

It is seen in Table 2 that commercial or predigested materials dominate the reading class. $62 \%$ of the subjects have said that the materials were collected directly from the market. And while there is a tendency to use very few adapted or adopted materials along with the commercial ones, there is no such teacher who either develops or adapts all the materials for their classes.

To find out about the genres used in the class, the subjects were given a list of them to be ticked. 
TABLE 3

GENRES OF MATERIALS USED IN THE CLASS

\begin{tabular}{|c|c|c|c|c|c|c|c|c|c|c|c|c|c|}
\hline \multirow[t]{2}{*}{ Question } & \multicolumn{13}{|c|}{ Genres used in the class } \\
\hline & Letters & Passages & $\begin{array}{c}\text { Short } \\
\text { Essays }\end{array}$ & $\begin{array}{c}\text { Advertise } \\
\text {-ments }\end{array}$ & $\begin{array}{c}\text { Newspaper } \\
\text { reports } \\
\text { /articles }\end{array}$ & $\begin{array}{c}\text { Conver- } \\
\text { sations }\end{array}$ & Dialogues & Notices & $\begin{array}{l}\text { Academic } \\
\text { articles }\end{array}$ & Menus & Maps & Poems & Instructions \\
\hline $\begin{array}{l}\text { 5. Tick } \\
\text { the types } \\
\text { of things } \\
\text { that you } \\
\text { dealt } \\
\text { with in } \\
\text { your } \\
\text { class. }\end{array}$ & 2 & 44 & 48 & 1 & 10 & 14 & 8 & 0 & 2 & 0 & 0 & 0 & 4 \\
\hline
\end{tabular}

Source: Field work, November, 2009

As Table 3 shows, the genres which were mostly used in the classes are short essays and passages. Other genres of authentic materials were almost never given to the subjects to work with.

In response to Question 6 (How difficult were the texts that you read?), 78\% of the subjects have said that they were 'not so difficult' while $14 \%$ have said that they were 'easy'. None have said that they were 'very easy'. And for $8 \%$ of the subjects the texts were 'very difficult'. So the level of the materials was not suitable for at least $22 \%$ students - they were either very difficult or too easy.

To find out what exercises they did in the class, the subjects were given another list to tick.

TABLE 4

NATURE OF EXERCISES DONE IN THE CLASS

\begin{tabular}{l|lc}
\hline Question & \multicolumn{1}{c|}{ Types of exercises done in the class } & Percent (\%) \\
\hline $\begin{array}{l}\text { 7. Tick the } \\
\text { exercises that } \\
\text { you did in the } \\
\text { reading class. }\end{array}$ & $\begin{array}{l}\text { Fill in the gaps. } \\
\text { Say true or false. }\end{array}$ & 94 \\
& $\begin{array}{l}\text { Answer questions with the information in the text. } \\
\text { Match the chunks to form sentences. }\end{array}$ & 76 \\
& $\begin{array}{l}\text { Express your own views or experiences. } \\
\text { Predict or guess the answers. }\end{array}$ & 38 \\
& Write the gist of the text. & 32 \\
\hline
\end{tabular}

Source: Field work, November, 2009

As Table 4 shows, the most frequently done exercises were filling the gaps (94\%), saying true or false (84\%) and answering comprehension check questions 
(76\%). On the other hand, the most rarely done exercises were writing the gist $(28 \%)$, predicting or guessing depending on given clues (32\%), expressing views or experiences (34\%), and matching the chunks to form sentences (38\%).

\section{Teachers}

Secondly, to collect data about the teachers' role, the subjects were asked 3 questions.

TABLE 5

TEACHERS' USE OF L ${ }_{1}$, GRAMMAR TEACHING, AND EFFORTS TO MAKE THE CLASS ENJOYABLE

\begin{tabular}{c|c|c|c|c|c}
\hline Questions & $\begin{array}{c}\text { Always } \\
\%\end{array}$ & $\begin{array}{c}\text { Often } \\
\%\end{array}$ & $\begin{array}{c}\text { Sometimes } \\
\%\end{array}$ & $\begin{array}{c}\text { Rarely } \\
\%\end{array}$ & $\begin{array}{c}\text { Never } \\
\%\end{array}$ \\
\hline $\begin{array}{l}\text { 8. How often did your teacher use } \\
\text { Bengali in the class? }\end{array}$ & 10 & 12 & 60 & 4 & 14 \\
$\begin{array}{l}\text { 9. How often did the teacher } \\
\text { discuss grammatical items? }\end{array}$ & 70 & 6 & 20 & 2 & 2 \\
$\begin{array}{l}\text { 10. Did the teacher try to make the } \\
\text { class interesting? }\end{array}$ & 0 & 2 & 10 & 30 & 58 \\
\hline
\end{tabular}

Source: Field work, November, 2009

In a reading class the teachers may try to make the meaning of the text clear to the learners by using $\mathrm{L}_{1}$ or explaining grammar if the meaning is embedded in it. In this regard, as it is seen in Table 5, whereas $14 \%$ teachers never used $\mathrm{L}_{1}$ in the class, $10 \%$ of them always did so. The rest of the teachers used both $\mathrm{L}_{1}$ and $\mathrm{L}_{2}$ in the class. As Ahmed (1999) has stated, the teachers are fond of grammar. $70 \%$ teachers 'always' discussed grammatical items, which is not desirable in a reading class. Teachers who 'sometimes' did it make up only $20 \%$ of the lot. Another thing to note is that $88 \%$ of the respondents are of the opinion that their teachers 'never' tried to make the class interesting.

\section{Learners}

Finally, in response to Question 11 (What did you mainly use to do in the class?), $94 \%$ of the respondents have said that they usually did the exercises which the teacher asked them to do. Among the other things, 22\% subjects discussed their problems with their teachers or their peers, $6 \%$ of them read or prepared things for 
other classes, and $2 \%$ did nothing in particular. So the students' role in the class seems to have been very passive.

\section{Post-reading Activities}

The interview-schedule had 3 questions to find out about the post-reading section of the class.

TABLE 6

TEACHERS' ROLE AS AUTHORITY AND ATTITUDE TOWARDS THE LEARNERS' FEELINGS

\begin{tabular}{l|c|c|c|c|c}
\hline Questions & $\begin{array}{c}\text { Always } \\
\%\end{array}$ & $\begin{array}{c}\text { Often } \\
\%\end{array}$ & $\begin{array}{c}\text { Sometimes } \\
\%\end{array}$ & $\begin{array}{c}\text { Rarely } \\
\%\end{array}$ & $\begin{array}{c}\text { Never } \\
\%\end{array}$ \\
\hline $\begin{array}{l}\text { 12. Did the teacher correct your } \\
\text { answers to the questions? }\end{array}$ & 68 & 20 & 2 & 6 & 4 \\
$\begin{array}{l}\text { 13. Did the teacher ask if you } \\
\text { enjoyed the activities in the } \\
\text { class? }\end{array}$ & 32 & 12 & 28 & 16 & 12 \\
$\begin{array}{l}\text { 14. Did the teacher change the lesson } \\
\text { plans if you requested? }\end{array}$ & 12 & 10 & 32 & 14 & 28 \\
\hline
\end{tabular}

Source: Field work, November, 2009

As it is seen in Table 6, 68\% subjects have reported that the teachers 'always' gave them the answers to the questions before they left the class. $88 \%$ of the respondents have said that the teachers used to ask them whether they enjoyed the class or not. As for the changes requested by the students, $28 \%$ of the subjects are of the opinion that they never noticed any such changes in the teachers' plans.

\section{Learners' Motivations and Opinions}

The courses were compulsory. So the researcher asked the subjects three questions to find out how they feel about the courses after they have done them.

TABLE 7

LEARNERS' FEEDBACK ABOUT THE COURSE

\begin{tabular}{ccccc}
\hline Question & Very Much (\%) & A Little (\%) & Not At All (\%) \\
\hline 15. Did you enjoy the course(s)? & $4 \%$ & $66 \%$ & $30 \%$ \\
\hline
\end{tabular}

Source: Field work, November, 2009 
Table 7 shows that $66 \%$ respondents enjoyed the course 'a little' while $30 \%$ of them did not 'at all'. So the classes were for most of the students boring and, consequently, ineffective.

The last question in the interview-schedule was to find out whether the subjects' attitude to the teachers and the materials used in the class was positive or not.

TABLE 8

LEARNERS' ATTITUDE TO THE TEACHERS AND THE MATERIALS

\begin{tabular}{c|c|c|c}
\hline Question & $\begin{array}{c}\text { Yes } \\
\%\end{array}$ & $\begin{array}{c}\text { No } \\
\%\end{array}$ & $\begin{array}{c}\text { No Answer } \\
\%\end{array}$ \\
\hline 16. Did you like your teacher and the things you read? & $28 \%$ & $70 \%$ & $2 \%$ \\
\hline
\end{tabular}

Source: Field work, November, 2009

In this regard, Table 8 shows that while only $18 \%$ of the subjects liked the teachers and the materials, as many as $70 \%$ of them did not.

\section{DISCUSSION}

From the analysis of the data it is easily discernible that while some of the established principles of teaching and learning reading skills in classroom environment are observed, many other important ones are not. Among the positive sides of the affair are the facilities of the classroom and the supplementary materials available. Although there are teachers $(24 \%)$ who either always or never use $\mathrm{L}_{1}$, $76 \%$ 'judicious' of them use both $\mathrm{L}_{1}$ and $\mathrm{L}_{2}$ in the class (see Table 5). Besides, the teachers are humane and care for the students' feelings (see Table 6) though they do not take steps promptly enough to satisfy some of the students.

But the things which the reading class lacks miserably are many in number and very serious in nature. Firstly, pre-reading activities in the reading class are not given their due importance. According to $43.33 \%$ of the respondents, these are never done (see the analysis under Table 1). Thought-provoking prompts and schema-building supplementary materials or discussion, which have been proved to be very important by so many studies, are hardly ever used in the class.

Secondly, the most alarming finding is the types of materials used in the class. The learners are not exposed to authentic materials: the materials are mostly commercial or predigested (see Table 2). They are not varied in their types either (see Table 3). As for the level of input, the materials are unsuitable for at least $22 \%$ of the students (see the analysis for question 6). Since they are not adapted, the 
materials do not relate to the subjects the learners are studying. In consequence, they are neither interesting nor effective.

Thirdly, the types of questions which the students deal with in the class are also flawed (see Table 4 and 5). The sorts of questions which require the learners to infer, interpret, predict, in short to use their cognitive faculty, are not given adequate attention. The teachers give too much attention to grammar and they hardly try to make the class activities interesting (see Table 5). Besides, the class is teacher centered. The teachers are the ultimate authority (see Table 6).

Finally, the learners are not all happy about the courses. Their motivation is mainly instrumental and extrinsic in nature. $30 \%$ of the learners do not enjoy the class at all and $66 \%$ only a little (see Table 7). Furthermore, their attitude towards their teachers and the materials is negative in most cases, which is a very big barrier in the way to the desired success. As many as $70 \%$ of the respondents like neither their teachers nor the materials used in the class (see Table 8).

Thus, efforts to implement the existing knowledge in this regard are hardly noticeable in the class. Therefore, it is not very difficult to realise why many of the BBA students, who complete the courses to improve English reading skills, do not really develop the skills on a remarkable scale.

\section{CONCLUSION AND RECOMMENDATIONS}

The courses offered to develop BBA students' English reading skills at many of the private universities are failing to achieve the desired goals. It is not because of lack of necessary resources, but because of the lack of interests on the part of the teachers in implementing the insights that we have gathered through studies in this area of knowledge. As the researcher hypothesized, some important findings gathered by empirical studies are hardly influencing the teaching-learning process which aims to develop the students' reading skills in the class. Pre-reading activities are getting little attention, and the learners are rarely exposed to materials which are suitable for them. In consequence, the learners are quite unhappy about both the materials and the teachers. Ultimately, they are not learning as much as they are expected to. But, there is no alternative to developing the students' reading skills. The study is important because it shows that the reading classes, on which the successes of the Bengali medium BBA students at the private universities largely depend, can be made more effective with a little more effort. The following are the researcher's recommendations: 
1. By means of a placement test, the university authorities should ensure that the levels of proficiency of the students in a particular class do not differ significantly.

2. The English teachers should adapt and adopt materials suitable for the students suitable in terms of the level of input and of being related to other BBA courses.

3. To do it successfully, they should ask the BBA teachers for help and cooperation.

4. The language teachers should be more careful about doing the pre-reading activities and making the other class activities interesting.

5. Developing suitable materials is a difficult and time-consuming job. So, the authorities of the universities should create opportunities for the teachers so that they can do these things.

The researcher believes that the immersion for the BBA students with Bengali medium background at the English-medium private universities will be less difficult and more successful if these recommendations are implemented.

\section{REFERENCES}

Ahmed, Sadruddin. 1999. "The Problem of Teaching English Grammar to Bengali-Speaking Students", Proceedings of the International Conference, Jan 31 - Feb 2, 1999: National and Regional Issues in English Language Teaching: International Perspectives, Dhaka: The British Council. p.172

Bhatia, H. R. 2004. Elements of Educational Psychology. Kolkata: Orient Longman Private Limited. pp.189-206

Brown, Douglas H. 1994. Principles of Language Learning and Teaching. New Jersey: Prentice Hall Regents. p.152

Deci, Edward, L. 1975. Intrinsic Motivation. New York: Plenum Press. p.23

Ellis, Rod. 1999. Understanding Second Language Acquisition. Oxford: Oxford University Press. pp.103-114

Finocchiaro, M and Brumfit, Christopher. 1983. The Functional-Notional Approach: From Theory to Practice. New York: Oxford University Press. pp.91-93

Krashen, Stephen and Terrell, T. 1983. The Natural Approach: Language Acquisition in the Classroom. Oxford: Pergamon Press. p. 32

Nunan, David. 1991. Language Teaching Methodology: A textbook for teachers. London: Prentice Hall. p.64

Tomlinson, Brian. 2003. Materials Development in Language Teaching. Cambridge: Cambridge University Press. p.viii

Ur, Penny. 2003. A Course in Language Teaching: Practice and theory. Cambridge: Cambridge University Press. p.150

Widdowson, Henry G. 1978. Teaching Language as Communication. Oxford: Oxford University Press. p. 16 